\section{HUBUNGAN ANTARA}

\section{PENGUASAAN KOSAKATA}

DENGAN KEMAMPUAN

\section{MENYIMAK BAHASA JERMAN \\ SISWA KELAS XI BAHASA}

\author{
Yulia Selviana', Misnah Mannahali' ${ }^{2}$, Ambo Dalle $^{3}$ \\ Universitas Negeri Makassar
}

Email: selviana.yulia@yahoo.com

\begin{abstract}
Abstrak. Penelitian ini bertujuan untuk memperoleh data dan informasi mengenai hubungan antara penguasaan kosakata dengan kemampuan menyimak bahasa Jerman siswa kelas XI Bahasa SMA Negeri 13 Bone. Penelitian ini merupakan penelitian deskriptif. Populasi penelitian ini adalah seluruh siswa kelas XI Bahasa yang berjumlah satu kelas dengan jumlah 28 siswa. Sampel penelitian ini adalah 28 siswa kelas XI Bahasa yang dipilih melalui teknik Total Sampling. Data penelitian dikumpulkan melalui tes tertulis penguasaan kosakata, kemampuan menyimak, dan dianalisis dengan menggunakan korelasi Product Moment. Hasil analisis data menunjukkan bahwa ada hubungan antara penguasaan kosakata dengan kemampuan menyimak bahasa Jerman siswa kelas XI Bahasa SMA Negeri 13 Bone Diperoleh hasil rhitung $=(0,574)>$ rtabel $=(0,374)$ dengan taraf signifikan $5 \%$.
\end{abstract}

Kata Kunci: Hubungan, Kosakata, Kemampuan Menyimak

\section{INTERFERENCE Journal of Language, Literature, and Linguistics}

\section{E-ISSN: 2721-1835 \\ P-ISSN: 2721-1827}

Submitted: July $12^{\text {th }}, 2020$

Accepted : August 12 ${ }^{\text {th }}, 2020$

Abstract. Correlation between Vocabulary Mastery with listening ability in German language Class XI students SMAN 13 Bone. Thesis. Faculty of Languages and Literature. State University of Makassar.This study aims to obtain data and information about the relationship between vocabulary mastery and te ability to listen to German in class XI language at SMA 13 Bone.This research is descriptive research. The population of this study was all studens of class XI Languages totaling one Class with 28 students. The sample of this study was 28 students of class XI language selected through total sampling techniques. Research data was collected through a written test, and analyzed using product moment correlation. The results of this study indicate that there is a significant link between mastery of vocabulary with the listening ability of German language class XI student SMA Negeri 13 Bone $R h=(0.574)>R t=$ (0.374) with a significant level of $5 \%$. 


\section{PENDAHULUAN}

Manusia sebagai mahluk sosial selalu berkomunikasi dengan sesamanaya, sehngga bahasa berfungsi sebagai alat komunikasi yang sangat penting. Melalui bahasa, manusia dapat mengekspresikan diri, perasaan, pikiran, keinginana, dan kebutuhannya, baik sebagai mahluk pribadi maupun sosial, serta menyampaikan banyak hal yang dirasakan, dipikirkan kepada orang lain maupun secara lisan.

Bahasa Jerman merupakan salah satu bahasa asing yang diajarka di Sekolah Menengah Atas (SMA), Sekolah Menengah Kejuruan (SMK), dan Madrasah Aliyah (MA) baik negeri maupun swasta. Dalam proses pembelajaran bahasa Jerman, seseorang dituntut untuk mencapai standar kompetensi yang menjadi acuan dalam penilaian kompetensi-kompetensi berbahasa Jerman. Kompetensi berbahasa yang dimaksud dalam hal ini terbagi menjadi empat, yakni menyimak (Hören), berbicara (Sprechen), membaca (Lesen) dan menulis (Schreiben). Selain keempat keterampilan berbahasa tersebut di atas terdapat pula dua aspek pendukung berbahasa yaitu gramatik (Strukturen) dan kosakata (Wortschatz). Kosakata merupakan unsur yang harus dikuasai oleh pembelajar bahasa asing untuk dapat memperoleh kemahiran berkomunikasi dengan bahasa tersebut, karena kosakata merupakan langkah awal dalam penguasaan keterampilan berbahasa .

Menyimak merupakan salah satu aspek penunjang dalam berbahasa. Kemampuan menyimak adalah aspek penting yang harus dikuasai oleh siswa.

Berdasarkan urian di atas, dan dari hasil wawancara guru mata pelajaran bahasa Jerman di katakan bahwa tingakat penguasaan kosakata dan kemampuan menyimak bahasa Jerman siswa kelas XI bahasa masih rendah, maka peneliti tertarik melakukan penelitian dengan judul "Hubungan Antara Penguasaan Kosakata dengan Kemampuan Menyimak Bahasa Jerman Siswa Kelas XI Bahasa SMA Negeri 13 Bone".".

Menurut Pringgawidagd(2002:17), Pringgawidagda (2012:14), Nurgiyantoro (2011:162), dapat disimpulkan bahwa kosakata adalah penguasaan dapat diperoleh secara tidak yang berifat informasi maupun secara tidak disadari dan bersifat formal. Sedangkan diutarakan oleh Tarigan (2011:3), Hiebert dan Kamil (2005:3), Djiwandono (2008:126) dan Scholl dalam Harum (2015:9) dapat disimpulkan bahwa bahwa kosakata merupakan semua kata yang terdapat dalam suatu bahasa dan merupakan pembendaharaan kata yang dimiliki seseorang.

Menurut Nurgiyantoro (2010:166), Zuchdi (1995:3), dan Nurgiyantoro (2010:338) dapat disimpulkan bahwa penguasaan kosakata merupakan kemampuan untuk memahami dan menggnakan kata-kata untuk mengungkapkan gagasan atau isi pikiran baik secara lisan maupun tulisan. Lehmann, Pilz, dan Sarich (2013:21), Nurgiyantoro (2010:166), dan Keraf (2008:22) dapat disimpulkan bahwa manfaat penguasaan kosakata bagi pengguna bahasa agar dapat mengemukakan ide, gagasan dan perasaannya kepada orang lain dengan berkomunikasi baik secara tulisan maupun lisan. Oleh karena itu, penguasaan kosakata sangatlah penting dalam kehidupan individu itu sendiri dan juga dalam kehidupan bermasyarakat atau sosial.

Menurut Alwi (1988:6) bahwa kelas kata berdasarkan jenisnya terbagi atas kata benda (nomina), kata kerja (verba), kata sifat (adjektif), dan keterangan 
(adverbial). Kridalaksana (1993:60) mengemukakan bahwa frasa nominal (FN) dapat menggambarkan peserta (orang, benda) uang diikutsertakan dalam peristiwaperistiwa (klausa-klausa dan kalimat-kalimat),biasanya nomina yang menjadi gatra induk (inti). Alwi (1998:163-171) menjelaskan frasa verbal dan fungsinya serta menjelaskan jenis-jenis frasa verbal saja. Frasa verbal mempunyai inti dan kata yang mendampinginya, Blickford dalam Achmad (2012:23-26) meyatakan Verba dalam bahasa Jerman terbagi ke dalam dua jenis yaitu schwarse Verben (kata kerja lemah) dan starke Verben (kata kerja kuat), Bilckford dalam Achmad (2012:28) menyatakan bahwa sesuai dengan grammatika tradisional, adverbial menerangkan adjektiva, adverbia lainya, verba atau seluruh klausa atau kalimat.

Selanjutnya Kushartanti dkk (2009:93), dan Robbins dan Judge (2008:57) disimpulkan bahwa kemampuan adalah kesanggupan atau keahlian individu untuk melakukan beragam tugas dalam suatu pekerjaan.

Menurut Saddhono, dan Slamet (2012:11), Tarigan (2008:31), Tarigan (2008:31), dan Nieweler dalam Seidl (2009:) dapat disimpulkan bahwa menyimak merupakan kegiatan mendengarkan lambang-lambang tersebut secara seksama dan menangkap lambang-lambang tersebut dengan penuh perhatian, pemahaman, dan apresiasi untuk memeroleh informasi maupun pesan yang tersimpan dalam bahasa lisan tersebut. Sedangkan Hermawan (2012:36-43), Tarigan (2008:63), dan Saddhono dan Slamet (2012:17) dapat disimpulkan bahwa terdapat beberapa tahapan dalam menyimak. Tahap-tahap tersebut dimulai dari mendengar, memahami, menginterpretasi, mengevaluasi, disimpulkan bahwa berbicara tujuan menyimak adalah memeroleh informasi, menangkap isi, serta memahami makna komunikasi yang disampaikan oleh pembicara melalui ujaran. Sedangkan menurut Tarigan (2008:37-53), mengklasifikasikan jenis-jenis menyimak menjadi dua jenis yaitu menyimak ekstensif dan menyimak intensif, Tarigan (2008:37-35) menyimak intensif di antaranya adalah:1) Menyimak kritis; 2) Menyimak konsentratif; 3) Menyimak eksploratif; 4) Menyimak introgatif; 5) Menyimak kreatif, Hermawan (2012;43-47) mengklasifikasikan jenis-jenis menyimak 1) Menyimak secara pasif, 2) Menyimak secara kritis, 3) Menyimak secara aktif, serta Kamidjan (2001:24), Astuti (2002:52) dapat disimpulkan bahwa menyimak aktif adalah sebuah aktivitas untuk mendapatkan atau menemukan informasi tambah pada sebuah topik dengan mendengarkan secara seksama serta memeriksa seberapa besar keakuratan pemahaman terhadap pesan-pesan yang disampaikan pembicara.

\section{METODE PENELITIAN}

Penelitian ini menggunakan dua variabel yaitu variabel bebas $(X)$ dan variabel terikat $(\mathrm{Y})$. Variabel bebas $(\mathrm{X})$ yang dimaksud adalah penguasaan kosakata dan variabel terikat $(Y)$ adalah kemampuan menyimak bahasa Jerman siswa kelas XI Bahasa SMA Negeri 13 Bone.

Penelitian ini merupakan penelitian deskriptif korelasi yang bertujuan untuk mengetahui hubungan antara penguasaan kosakata dengan kemampuan menyimak bahasa Jerman siswa kelas XI Bahasa SMA Negeri 13 Bone.

Populasi dalam penelitian ini terdiri atas satu kelas yaitu kelas Bahasa dengan jumlah keseluruhan 28 siswa. Mengingat jumlah populasi yang tidak terlalu 
banyak, maka digunakan sampel total (total sampling). Sampel dari penelitian ini yaitu kelas XI Bahasa SMA Negeri 13 Bone.

\section{HASIL DAN PEMBAHASAN}

Data hasil penelitian pada tes penguasaan kosakata terdiri atas empat jenis tes. Tes tersebut adalah tes mencocokkan kalimat dengan kata benda (Nomen), tes melengkapi kalimat dengan kata kerja (Verben), tes mencocokkan kata sifat (Adjektif), dan tes penguasaan kata keterangan (Adverb). Skor maksimal pada tes penguasaan kosakata adalah 21. Berdasarkan hasil analisis data, diketahui bahwa skor rata-rata yang diperoleh siswa pada tes penguasaan kosakata adalah 17,21 dengan tingkat penguasaan $82 \%$.

Data hasil penelitian pada tes kemampuan menyimak terdiri atas dua jenis tes. Tes tersebut adalah tes pilihan ganda, dan tes melengkapi paragraf. Skor maksimal pada kemampuan menyimak 25. Berdasarkan hasil analisis data, dapat diketahui bahwa nilai rata-rata yang diperoleh siswa adalah 16,67 dengan tingkat penguasaan $55,60 \%$.

Skor yang diperoleh siswa pada penguasaan kosakata dan kemampuan menyimak bahasa Jerman dianalisis dengan menggunakan teknik korelasi Product Moment. Dari hasil perhitungan diperoleh hasil bahwa $r_{\text {hitung }}$ lebih besar daripada $r_{\text {tabel }}\left(r_{h}>r_{t}\right)$ yaitu 0,574 $>0,374$. Dengan demikian, dapat disimpulkan bahwa terdapat korelasi yang signifikan antara penguasaan kosakata dengan kemampuan menyimak tes bahasa Jerman. Hal tersebut menunjukkan bahwa penguasaan kosakata merupakan salah satu faktor yang mempengaruhi kemampuan menyimak bahasa Jerman siswa.

\section{KESIMPULAN}

Berdasarkan analisis data yang telah dipaparkan sebelumnya, maka dapat disimpulkan bahwa penguasaan kosakata bahasa Jerman siswa dengan nilai ratarata sebesar $81,92(81,92 \%)$ termasuk kategori Baik Sekali, sedangkan tingkat Kemampuan menyimak dengan nilai rata-rata 64,85 (64,85\%) termasuk kategori Baik. Hasil analisis data tersebut menunjukkan bahwa terdapat hubungan yang signfikan antara penguasaan kosakata dengan keterampilan berbicara bahasa Jerman, yang ditunjukkan dengan koefisien korelasi sebesar $r_{h} 0,574>r_{t} 0,374$ yang termasuk pada kategori sedang.

\section{DAFTAR PUSTAKA}

Achmad, A. K. (2012). Analisis Kalimat Majemuk Bahasa Jerman. Makassar. Tesis. Program Sarjana UNHAS.

Alwi, H. (1998). Tata Bahasa Baku Bahasa Indonesia (Edisi Ketiga): Balai Pustaka

Astuti. (2002). Menyimak. Jakarta: Depdikbud.

Djiwandono, S. (2008). Tes Bahasa. Jakarta: PT Indeks

Harum, A. (2015). Hubungan Antara Penguasaan Kosakata Dengan Kemampuan Membaca Memahami Teks Bahasa Jerman Siswa Kelas XI IPA 7 SMA Negeri 1 Makassar. Skripsi: FBS UNM 
Hermawan, H. (2012). Menyimak Keterampilan Berkomunikasi Yang Terabaikan. Yogyakarta: Graha Ilmu.

Hiebert, E. H. dan Michael L. K. (2005). Teaching and Learning vocabulary. London: Lawrence Erlbaum Associates, Publischer

Kamidjan. (2001). Teori Meyimak. Surabaya: FBS UNESA

Keraf, G. (2008). Diksi dan Gaya Bahasa. Jakarta: Gramedia Pustaka.

Kridalaksana, H. (1993). Kelas Kata dalam Bahasa Indonesia. Jakarta: Gramedia Pustaka Utama.

Kushartanti, dkk. (2009). Pesona Bahasa Langkah Awal Memahami Linguistik. Jakarta: PT. Gramedia Pustaka Utara.

Lehmann, Astrid, Pilz, Annet, dan Sarich. (2009). Sprachsensibler Fachunterricht: Brandenburg.

Nurgiyantoro. (2010). Penilaian dalam Pembelajaran Bahasa dan Sastra. Yogyakarta. BPFE.

Nurgiyantoro. (2011). Penilaian dalam Pembelajaran Bahasa dan Sastra. Yogyakarta. BPFE.

Pringgawidagda, S. (2002). Strategi Penguasaan Berbahasa. Yogyakarta: Adicitra Karya Nusa.

Robbins, S. P. dan Thimothy A. J. (2008). Perilaku Organisasi (Organosation Behavior), Jakarta: Salemba Empat.

Saddhono, K. dan St. Y. Slamet. (2012). Meningkatkan Keterampilan Berbahasa Indonesia (Teori dan Aplikasi). Bandung: Karya Putra Darwati.

Seidl, L. (2009). Hörverstehen in Theorie und Praxis. GRIN Verlang. Norderstedt Germany. Diakases pada tanggal 8 Maret 11.00 WITA dari Word Wide Web.

Tarigan, H. G. (2008). Menyimak Sebagai Suatu Ketrampilan Berbahasa. Bandung: Angkasa.

Tarigan, H. G. (2011). Pengajaran kosakata. Bandung: Angkasa.

Zuchdi, D. (1995). Strategi Meningkatkan Kemampuan Membaca Pemahaman Bacaan (Suatu Terjemahan). Yogyakarta: FPBS 